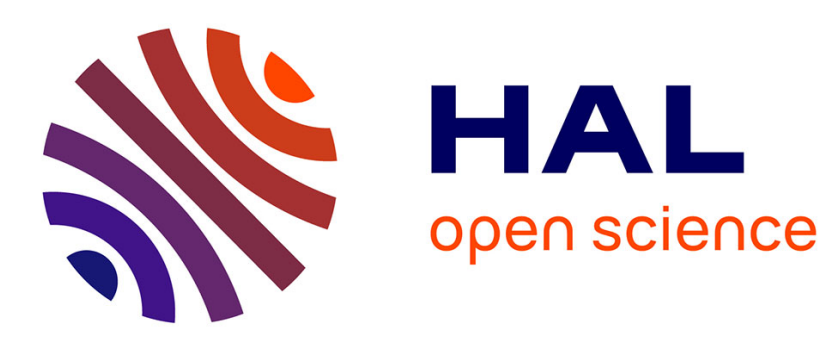

\title{
Parents at their best: The ethopolitics of family bonding in France
}

Sébastien Roux, Anne-Sophie Vozari

\section{To cite this version:}

Sébastien Roux, Anne-Sophie Vozari. Parents at their best: The ethopolitics of family bonding in France. Ethnography, 2017, 0, pp.1 - 22. 10.1177/1466138116687592 . hal-01576826

\section{HAL Id: hal-01576826 \\ https://hal.science/hal-01576826}

Submitted on 3 Sep 2019

HAL is a multi-disciplinary open access archive for the deposit and dissemination of scientific research documents, whether they are published or not. The documents may come from teaching and research institutions in France or abroad, or from public or private research centers.
L'archive ouverte pluridisciplinaire HAL, est destinée au dépôt et à la diffusion de documents scientifiques de niveau recherche, publiés ou non, émanant des établissements d'enseignement et de recherche français ou étrangers, des laboratoires publics ou privés. 


\title{
Parents at their best: The ethopolitics of family bonding in France
}

\section{Sébastien Roux}

@SAGE

Cnrs, Lisst, Toulouse, France

\section{Anne-Sophie Vozari}

Ehess, Iris, Paris, France

\begin{abstract}
In France, the concept of 'parentality' has become a key notion in the field of social work since the mid-1990s. This idea serves mostly as a basis for professional evaluations of parents' ability. However, it does not only prescribe behaviors and implement norms; it has also transformed the way people consider their own family attachments, and adjust individually to new ethical definitions of selves. Based on two complementary ethnographic field studies - one looking at the administrative management of adoption and the other at medical care provision for maternal mental health - this article shows how discourses and practices about parentality serve a policy of self-reform. This article therefore questions how politics of control and regulation that are deployed in the privacy of the family sphere act on an ethical level by inviting subjects to reform themselves for their own good and for the good of others.
\end{abstract}

\section{Keywords}

ethopolitics, family, parenting, government, institutions, subjectivity

Sylvie, 33 years old, is eight months pregnant when she first meets with a psychologist in the perinatal psychiatric department. Originally from Mali, she came to France at the age of eight and later graduated from a business school. She appears demoralized during her consultation, walking slowly and heavily, her back bent and her eyes riveted to the ground. She seems completely overwhelmed. She is finding her second pregnancy very difficult, to the extent that she is having trouble

\section{Corresponding authors:}

Sébastien Roux, Cnrs, Lisst, University Toulouse Jean Jaurès, 5 allée Antonio Machado, 31058 Toulouse, France.

Email: sebastien.roux@ehess.fr

Anne-Sophie Vozari, PhD Candidate, Ehess, Paris Iris, 190-198 avenue de France, 75013 Paris, France.

Email: annesophie.vozari@gmail.com 
sleeping and eating. Sylvie's general practitioner convinced her to make an appointment after realizing that she was practically not eating.

Sylvie has found out about this unwanted pregnancy late, and has hesitated for some time before deciding to carry the fetus to term. The child's 'father' lives abroad and has no intention of moving to France. Sylvie already has one sevenyear-old child from a previous marriage, and she divorced her husband (an engineer in the public buildings and work sector) several years ago. She had not planned on having any more children, believing that she "would finally be able to devote herself' to her career. Sylvie has recently been hired as a temporary consultant, but she revealed her pregnancy too soon and her employer did not renew her contract. She recounts her situation to the psychologist with a great deal of emotion, confiding feelings that she has 'never told anybody':

I'm angry.

What are you angry with? Who exactly are you angry with?

[Sylvie stays silent for a moment while crying discreetly, before slowly starting to speak again]. I'm cross with myself for being pregnant and I'm cross with myself for being cross. [silence] I don't recognize myself anymore. The only thing I feel is that he's moving. [tears] But it's not his fault. What's it going to be like... I don't know what kind of relationship I'm going to be able to build with this child.

Mr. and Mrs. Louvier are a married couple in suburban Renangeours, the prefecture of a urban county in the west of France. They are both 43 years old. He runs a small grocery store; she provides domestic aid to seniors. Four years ago they obtained the required French administrative authorization to adopt a child. The Louviers are meeting today with a social worker named Jocelyne, as they recently received a proposal from a Russian orphanage. The couple seems extremely confused, and stressed: 'What if the child is unhealthy, finally?' 'What if someone in Russia claims at the last minute to be a member of the child's family?' 'What if they suddenly change their decision?' 'What if the local judge refuses our application?' Jocelyne smiles, and reassures the couple: 'But you already know the answers to all these questions. We've been working a lot since we first met. I'm sure you're ready.' The Louviers begin to relax and, in fact, to answer for themselves many of the questions they had addressed to Jocelyne just a few minutes before. 'Yes, you're right, we know. You taught us everything already.' Mr. Louvier pauses, quite moved, before finally adding: 'Once there, it will be the time we would have needed you the most... Will we be good parents?' Jocelyne replies gently: 'Sure you'll be. You did a good job. You're ready now. You've been selected as you learnt how to be.'

These two ethnographic scenes took place in different French cities a few weeks apart. During a prenatal consultation, a trained psychologist listens to a pregnant woman in distress before reassuring her that she will manage, with time and hard work, to 'properly' love her child to come. A social worker specialized in the field of 
transnational adoption congratulates two parents-to-be for the 'quality' of their preparation and adjustment. In neither of these cases are the adults yet parents; however, they are already controlled, framed, trained, advised, and helped by professionals whose work is to conform their feelings and agencies to the 'child's best interest' and to support them in the process of turning themselves into 'good' parents.

In both contexts, the work conforms to a 'risk reduction' policy. In the first case, which concerns the provision of maternal mental health care, the treatment is meant to prevent the mother's depression from causing psychic damage to the child. In the second case, during the adoption process, the inquiry aims to ensure, to the greatest extent possible, that the applicants will fulfill their parental function in a correct manner, with respect to a traumatized child 'who has already been abandoned once' (Homans, 2006). More broadly, scholars have documented how be(com)ing a parent - and behaving accordingly - has been framed as a difficult task requiring institutional intervention. Because of a heightened sense of risk associated with parenting, mundane parental activities are often perceived as putative dangers for the child (Furedi, 2002; Faircloth et al., 2013; Lee et al., 2014). 'Parental determinism', as Frank Furedi (2002) puts it - i.e. the idea that the kind of adults infants become depends upon the way they have been treated by their parents, particularly their mothers - results in an increased surveillance and control apparatus.

France is no exception. Since the mid-19th century, with the advent of the first child protection laws and moral reform philanthropist initiatives (Fuchs, 1984; Lynch, 1988), France has seen ever-increasing state interventions in the realm of family functioning. Public monitoring of private relationships has progressively expanded. Throughout the 20th century a set of specialist administrative bodies was developed, many of which were tasked (or tasked themselves) with a monitoring role: defining, regulating, and managing how families functioned. For a long time, social sciences critically approached these state workers as coercive public agents whose primarily aim was to police (lower-class) families via mechanisms of control, surveillance, and restriction (Donzelot, 1979). However, these workers do more than this. In disseminating situated discourse about children and their 'needs' and 'expectations', state agents play a decisive role in creating a consensus about the universalized needs of a whole generation and - by extension - about how parents should act towards their offspring. Thus, by defining children's requirements and deploying practical and discursive techniques to fulfill them - ensuring the children's wellbeing - these institutions are actively working towards not only determining the 'proper' way of performing parental duties, but also towards 'parenting the self ${ }^{1}$ of the individuals they support.

Thus, by investigating how they directly act - or at least aim to act - upon how (future or current) parents imagine themselves, and how such individuals work towards self-improvement by cultivating their own sense of identity to become the valorized subjects they desire to be (Laidlaw, 2013), we aim to demonstrate that these institutions are more than just an apparatus of control for reforming and redressing subjects through power and sanctions. By focusing on familial intimacy 
and its institutional management, this article aims to question how individuals reform themselves, in order to become subjects newly 'able' to, and 'capable' of, acting as conformed parents. Based on a dialogical study of two separate institutions in the broad field of child protection, one in care provision surrounding birth and the other in adoption, and with the aim of understanding these forms of government which transform subjects' relationships with themselves and others, our intention is to question the ethical and political ramifications of becoming a parent.

\section{Methods and ethics}

In 2013, we conducted two separate ethnographic fieldworks that were not at the time conceptualized as systematic comparisons a priori. However, once the studies had been conducted, we understood afterwards that they both revealed how professionals' actions toward the promotion of family bonding progressively lead the subjects to reconsider their own desires and abilities, and to normalize themselves of their own free will by subscribing to the self-questioning process that is expected of them.

Focusing on the institutional management of motherhood around birth, the first ethnographic investigation was conducted during six months within a large maternity unit in the Paris area. The study involved child psychiatrists and clinical psychologists in charge of maternal mental health (before and after birth). Having a child is not necessarily a 'happy event' - it may also be a period highly charged with conflicting emotions: sadness, anger, and confusion number among the socially unacceptable feelings that mothers may experience or express (Taylor, 1996). As, in France, contraception and abortion are supposed to offer women the possibility of carrying only 'desired' children, the mainstream procreative norm which posits that being 'subjected' to motherhood (or having an 'unwanted' pregnancy) is aberrational thus reinforces the shared expectations that concern requisite love. When a woman 'fails' to experience the expected feelings of love and fulfillment once pregnant and, even worse, once her child has been born, professionals may intervene in order to allow her to 'become a mother', i.e. a woman who is at peace with (her) motherhood, and who is fully realized as a mother (Davis-Floyd, 2004). In a context marked by the growing institutionalization, medicalization and psychiatrization of affective deviance when procreation is involved (Lee, 2004), these women receive treatment and care. ${ }^{2}$ More than 50 psychotherapy consultations were observed on a weekly basis between January and July 2013; they offered a way of understanding how women are worked upon within and beyond the institution to bring affects and desires into line. To that end, both care and cure were considered as the medium for self-transformation, and a way for professionals to encourage patients to succeed in becoming 'mothers like everyone else'.

A second investigation was conducted between May and August 2013 in an adoption bureau in the west of France, which was observed on a daily basis. A total of nearly 350 hours was spent in this institution, divided between interviews 
and observations of the institution's various tasks and activities (evaluations, home visits, commissions, networking between associations, collecting children, matching children with families, etc.). In France, anyone who wants to adopt a child must first obtain administrative authorization, which is valid for a period of five years and is delivered by the district services in charge of child protection - an 'agrément' (approval). However, this institutional assessment also serves as an educational process aimed at 'supporting' putative parents along their 'path' towards parenthood. ${ }^{3}$ For the - predominantly female - professionals who work in this institution, the particularly fragile situation of a child who is up for adoption justifies the establishment of a highly reinforced framework, which 'makes the most of the waiting period' so parents can 'further specify and work upon their plans'. To that end, professionals - designated by Signe Howell as 'psycho-technocrats' (Howell, 2006) - encourage applicants to 'project themselves' into the future, so that they can 'become aware' of the specific features of adoption and, even better, 'verbalize' them. As, over the past decade, global rates of international adoption have fallen dramatically, this period of institutional framing can last for years. Candidates do not always obtain a child during the five-year validation period of their first agrément. They are either encouraged to renounce their initial project, or they are invited to go through the same procedure again, thus remaining under the gaze of the institution for a duration that can sometimes reach a decade.

Despite the specificity of each fieldwork's topic and context, we found resonance between the two objects of study. In both cases, a public institution transforms intimacy, ethics, and subjectivities by acting, through constraint and help, on individuals' wills and desires to become a proper parent. By focusing on this process, we aim at questioning how individuals are publicly framed, not only to be more efficiently controlled and supervised, but also to adhere to new ideals and beliefs about the (better) people they desire to be(come). We have decided to analyze this process not by comparing institutional techniques, but rather by focusing more on the significance of such a coincidence (Boellstorff, 2007) in the treatment of patients and applicants.

We applied similar ethical concerns in the conduct of both fieldworks. Ethnographic data have been collected with the agreement of every person involved (both professionals and parents-to-be). We systematically announced that our presence would have no consequence on the way professionals acted or evaluated their cases. Each time someone refused our presence, we withdrew from the situation observed. Names of persons and places have been modified to guarantee full anonymity, and no data involving minors have been integrated in our analyses.

\section{'Parentality' and the gendered work of institutions}

In the early 1990s, in a context strongly characterized by concerns about security and juvenile delinquency, a buzzword emerged in France as the focus of a political debate concerning allegedly incompetent and irresponsible parents who were seen as having 'abdicated' their duties. The term 'parentalite' (parentality) came to 
designate a new public issue: that of how to exercise 'parental function' (Martin, 2003). It has been mobilized ever since as a new resource for public intervention. As a consequence, the concept now has evaluative connotations. No longer confined to describing the roles and attributes of parental parties, it also aims to diagnose potential individual failings, and is used in a clinical perspective to determine parents' capacity to 'take on their role' and 'fulfill their duties' towards both their children and public order. Originally introduced in French ${ }^{4}$ in order to distinguish parental functions from parents' statuses (Godelier, 2012; Goody, 1982), the neologism labels both the ways of being and becoming a parent. ${ }^{5}$ Indeed, the notion takes a constructive and dynamic perspective; it posits that being a parent is never self-evident, whether naturally or socially, and instead results from a psychological process that matures over time and with practical experience. The concept quickly spread amongst social workers and psychologists to qualify and evaluate family bonds and attachments, morally and technically. Nowadays, the idea of parentality is more broadly used to qualify the way current or future parents consider themselves, their abilities, and the kind of idealized parents they want to become. As such, the term encompasses the moral judgments that adults formulate about themselves and others, including competencies and possibilities for self-improvement, towards an idealized model of so-called 'good' and/or 'better' parenting. It can be understood as an 'identity work' (Faircloth, 2013), where adults - both women and men - make themselves into mothers and fathers, while under the gaze of relatives, friends, neighbors, and private and public institutions.

However, the use of gender-neutral terms such as 'parents', 'parenting' and 'parentality' tends to obscure the unequally gendered expectations which are demanded of parents. As women are expected to turn into 'mothers' and men into 'fathers', professionals deploy strategies that produce and reproduce normative gender attributes. Indeed, despite a more egalitarian approach to parenting that emerged in the early 1990s, which calls on fathers to become more involved in child-rearing (Lupton and Barclay, 1997), contemporary ideologies of parentality continue to attribute divergent - but ostensibly 'complementary' - parental responsibilities to both sexes. Contemporary ideologies of motherhood still frame mothers as the main figures of juvenile attachment (Apple, 2006; Hulbert, 2004), urge them to devote higher levels of attention and affection to their children (Hays, 1996), and promote unconditional love (Lupton, 2000). Fathers, on the other hand, are supposed to express a sense of authority and responsibility from a more distant parental position. If their love is still considered a necessity, fathers are invited to 'acknowledge' and 'accept' the preeminence of motherhood 'in the child's best interest', and to find 'their place' (socially positioned) a 'bit further' from the child. As such, if both sexes are supposed to experience their roles 'positively' and to find in them a sense of fulfillment and self-realization, institutional education with respect to parentality also naturalizes gender ideologies, and compels individuals to adhere to specific affects and expectations. 'Parenting the self' is a process that 'mothers' first. 


\section{Turning yourself into a mother}

Johanna is a petite brunette, aged 31, with Asian features and a neat bob. She is six months pregnant when she comes to her first appointment alone, after having been encouraged to do so by her midwife. As she sits in the empty corridor that serves as a waiting room, she has an inscrutable expression on her face but smiles broadly when the psychologist arrives. Once seated at the coffee table in the psychologist's office, her face clouds over again. In tears, this young international marketing and communications assistant explains that she suffered two years ago from a long bout of depression after her first daughter was born. Johanna never talked about the aftermath of her previous pregnancy, and was downhearted when the child arrived. According to her, there had been nothing to predict that malaise, which she still could not explain. However, she feels like it is happening again. She says that she feels quite bad, cries often, has panic attacks, and is unable to tell anyone about her feelings - not even her partner. She says she has come here to avoid 'falling back into the same thing again'.

I can't seem to be happy; I just can't do it. I'm scared of sending bad vibes to the baby. Sometimes I think... [she hesitates a moment and then blurts out, between sobs] I'd have wanted not to be pregnant. I'm ashamed. [...] I don't understand what's happening to me. I don't understand why I'm like this. [...]. In the expectant mum's yoga class, at the end, during the relaxation part, they often tell us to imagine ourselves with the baby lying against us. I can't seem to imagine it. But we wanted him. I wanted this baby. [... I I feel like I'm a monster. I can't even manage to pretend anymore, to smile. [tears] As soon as he moves, I don't feel well. As things stand today, I don't know how to love him.

First appointments often give rise to self-examination, confession and 'avowals' (Foucault, 2014a) marked by silence and tears, in which women are encouraged to explicitly express their guilt about not feeling happy about birth, whether for themselves or for their child. When Johanna puts her guilt into words, she expresses not only pain that might require treatment, but also her desire for both conformity and a healthy relationship with herself. She reveals everything she is not yet, and wants to become. She is regretful and bitter about the distance separating her from 'normalcy'. She wants to be like other women, comparing herself with a perceived incarnation of happiness; she explains that '[i]n the prenatal swimming class, I see all these women who are happy. I'd like to be like them. But it's not how I feel inside'. Contrary to some women who might feel alienated from their 'true selves' during pregnancy (Bartky, 2003) - largely due to the bodily transformations experienced pre- and postpartum (Fox and Neiterman, 2015) - Johanna feels alienated from herself, and desperately tries to connect with the 'real' and 'normal' psychic and corporal ways of becoming a mother. The logic of avowal lifts the veil from these hopes and disappointments. The depth of the desire for 
self-transformation - on the part of both patient and professional - thus gives a substantial hold to governmentality in the therapeutic relationship.

Three months after Johanna first consulted the psychologist, she comes back to her final consultation with a smile on her face and her baby in her arms. He was born two weeks earlier and she wants the psychologist to meet him.

So, how are you now?

Better and better.

Good.

[...] I'm a bit apprehensive but I'm OK. I still can't seem to feel happy but let's say I don't feel bad. [...] I'm not the same Johanna as before [...] The first times I came to see you I was expecting a miracle solution. There was no solution but it's a miracle. [...] It's like the solution was to say it all, to get it all out [the psychologist nods her head]. I'm not over the moon every day, you know, but I manage to feel things whereas before I was empty all day long. [...] I'm trying to take things as they come and that's all. [...]

\section{Well done!}

Today, I accept it, I don't lie anymore. I tell the truth and I accept it. [...] Now I'm pleased even if things aren't exactly great either.

Yes...there's still the 'not exactly great either'. But you've come so far!

Johanna 'has come so far' that she is now able to no longer be 'perfect' but, as she explains, just 'comfortable with who she is'. This journey taught her to listen to herself. It also - 'miraculously' - brought her to discover her 'true self' and 'accept' who she is and who she can be: a serene, if not completely fulfilled, mother. Through the work she realized and, with the help of the psychologist's interpretations, she declares now to understand the subconscious reasons behind her distress (which were identified as belonging to her childhood, as is often the case ${ }^{7}$ ). By giving shape and meaning to present experience, the therapeutic support process aims for the patient not only to call herself into question but also to find answers in her lived experience.

'How will I manage to be a (good) mother?' Women who are uncertain - and often tormented - about their emotions and abilities seek the answer to this question while under the scrutiny of a medical and psychological gaze, one that compels them to reconsider themselves. They are encouraged to see themselves differently as conforming, as acceptable - in order to eventually find peace. This provision of care should be understood as a deliberate endeavor to break with a particular biographical perspective. The patients are brought to a point where they can 'let 
go' of the subject they have been or would have wanted to be, thus allowing a different self to emerge - a self that is, according to professionals - more 'accurate', more 'authentic', more 'real'. The aim is not so much to produce 'good mothers' by dictating particular ways of behaving or not behaving as it is to fashion maternal subjects who are at peace with their failings and aware of their potential. In order to achieve this, these women are urged to only 'listen to themselves', to take a step back from the normative expectations of so-called 'society' and to detach themselves from the guilt-laden words of their peers. During the consultations, a patient's relatives (inevitably female: mothers, mothers-in-law, sisters, etc.) are often mentioned as potentially toxic figures whom she should try to avoid being with or listening to too carefully. Women in distress have to find the 'truth' of the bond tying them to their children within themselves. While much of the consultation is geared towards increasing self-awareness and autonomy vis-à-vis ideologies of motherhood, the apparatus therefore works, paradoxically, towards 'naturalizing' the mother-child bond, thus reaffirming it. ${ }^{8}$ Indeed, the care provided works by presupposing that maternal attachment is an alienated instinctual substratum to be rediscovered and allowed to express itself.

\section{Gestation}

However, institutional support in the field of parentality is not only about introspection and self-transformation for which the goal is a better level of 'well-being' and happiness. It is also a way of subjectivizing, insofar as it helps individuals to correct themselves by incorporating new values and beliefs, leading them to transform their own views about the individuals they desire to become.

May 2013. Today, Simone Nabon - a social worker from the Adoption Bureau - visits the Durands and their two sons, Antoine and Nicolas. Mr. Durand is a wealthy architect; Mrs. Durand used to be a schoolteacher but stopped working when the kids arrived. The Durands tried for years to conceive a child before running medical tests; Mr. Durand was then diagnosed with azoospermia, with no chance to procreate. After several months of consideration, the couple decided not to seek a sperm donor, but rather to turn to international adoption. The Durands obtained their certification five years ago, without difficulties. As they were respectively 41 and 39 years old when they started this process, the Durands asked for two children at the same time, as the couple thought they 'would be too old to adopt again later'. They obtained their sons relatively quickly, as few parents are willing or prepared to adopt a pair of brothers. ${ }^{9}$ Antoine and Nicolas were born in Bulgaria from an unknown mother. Their original names - Anton and Nikolaïhave been slightly modified by their adoptive parents.

Mrs. Durand is home with her sons. Antoine is now seven, Nicolas five. She invites us for a coffee, while the kids are playing in their bedroom. After the usual small-talk, the social worker starts asking questions about the children: 'How are they doing?', 'What about school and kindergarten?', 'What is their health condition? Do they have any friends?', 'Have they maintained some 
contacts with Bulgaria?'... Each time, Mrs. Durand replies smoothly, with a peaceful smile:

'The kids are doing fine. It was a bit more difficult for Antoine, at the beginning. As you know, he suffered a bit from enuresis [bed-wetting], but we let him take all the time he needs. No pressure.' [...]

'We're very happy with school. We warned their teachers, and all the professionals seem very open to the specificities of adoption.' [...]

'We go every three months to meetings organized by EFA [a French NGO dedicated to adoptive families and adoptees]. There, the kids have friends. And we're lucky: there is a little boy from the same Bulgarian orphanage just a two hour ride from home. We've been seeing them a bit, so the kids can reunite.' [...]

'They ask questions sometimes about Bulgaria. But we know it's normal. And they can have access to pictures, and stuff. It's important they know their stories'.

Each time Mrs. Durand replies, the social worker nods and writes comments in her black notebook. She seems very satisfied with the dialogue. These two women have known each other for years and, unlike some previously observed evaluative sessions - such as during the certification processes - the discussion remains smooth and gentle. After roughly 30 minutes, Simone Nabon expresses the wish to see the boys. Their mother agrees instantly and calls for them. Antoine and Nicolas join us for a bit, and Simone starts chatting with them. They both communicate in perfect French, with no trace of an accent. They smile at her; they talk about the games they like, the friends they have, and the sports in which they participate. Everybody seems relaxed and friendly. The visit ends after one hour. Mrs. Durand escorts us to the car. She has never expressed any worries or concerns about the follow-up report; she already knows there is unlikely to be any problem. The happiness of her boys is already, in itself, the sign of success. With a large smile, she shakes Mrs. Nabon's hand and asserts: 'Thanks again for everything you did. Your advice really helped us. With you, we knew how to behave with language, family, school, everything... And this is really the best for the boys'. The social worker replies quietly: 'You're welcome. This is why we're here. And you know you can call us whenever you want'. We leave. Simone drives us back to the bureau. On the way, she turns to me and adds: 'She'll be a great adoptive mum. She understood everything'.

In France, adoption is a very long process, systematically punctuated by frequent institutional hurdles. Candidates are expected to acquire skills, knowledge, and competencies to obtain their certification. Then, they have to deal with uncertainties, anxieties, and time - always under the gaze of professionals whose task is to assess the way people deal with pressure, augmenting their support with constant evaluation. Then, once the child or the children arrive, parents must put into 
practice - discursively and practically - all the dynamic and variegated knowledge they are expected to have integrated and incorporated during the previous years. As such, if this ethnographic scene may appear banal, it is not meaningless: On the contrary, it shows how time helps to produce consensus between professionals and parents throughout the adoptive process - rendering evident and universal a certain type of knowledge and a specific core of 'good practices'.

A social worker from the Bureau once said: 'Adoption is like pregnancy. You wait. You expect. You get ready. However, you never know how long it's going to take.' Obviously, this comment highlights the uncertainties inherent to adoption. But it also unifies these two ways of engendering, aligning adoption with procreation. Indeed, if 'adoption is like pregnancy', it is because what matters first and foremost is - according to professionals - that this duration is rendered productive by acting upon oneself to turn oneself into a parent. To 'wait', to 'expect', and to 'get ready' are perceived as productive ways of welcoming the child-to-come by transforming the one-who-waits into the parent he or she should be. Thus, this social worker was right: adoption, like pregnancy, is a process shaped by professionals who intervene, cure, monitor, correct, teach, support, etc. As such, these professionals act, in order to make sure that parentality exists; that is to say, to transform parenthood into a (self-) surveilled connection in which bonds are always-already problematic enough to justify their presence - and always in the best interest of all parties involved.

\section{Direction and constraints}

Discourses about parentality are embodied in institutional practices where professionals in social work, medicine and psychology emphasize 'support' and 'guidance' rather than protection and repression. From this perspective, being a parent is less a given family role than an identity to construct on a daily basis. It is not enough to be and act like a parent, it is necessary to constantly become one. In this sense, parentality is not just a moralizing discourse that serves as a medium for normalization, it is also an instrument of government.

Above all, the notion of parentality operates on how people consider, question, judge, assess, and conceive of themselves; and it ultimately transforms individuals' reflexive relationship to themselves. Thus, the subjectivity of the governed is not so much denied as it is included in the very processes that lead to their subjectivization. Subjects are freely called upon to consent to the power that will change them as it is exercised upon them. As such, this particular form of managing and producing subjectivity can be seen as a relationship of 'direction'. In his 1979-80 Lectures at the Collège de France (entitled On the Government of the Living), Michel Foucault gave substantial weight to this technique of government. He explained that:

I think the true relationship of direction is that it fixes as its goal, not something like the wealth or health of the person who is directed, but something like perfection, or 
tranquility of the soul, or the absence of passions, self-control, beatitude, that is to say a certain relationship of self to self. [...] Basically, the formula of direction is this: I freely obey what you will for me, I freely obey what you will that I will so that in this way I may establish a certain relationship to myself. And as a result, if we call subjectivation the formation of a definite relationship of self to self, then we can say that direction is a technique that consists in binding two wills in such a way they are always free in relation to each other, in binding them in such a way that one wills what the other wills, for the purpose of subjectivation, that is to say access to a certain relationship of self to self. (Foucault, 2014b: 231-2)

Although a hierarchical relationship does distinguish the director from the person being directed, the aim is for the latter to want what the former wants, for them to remain themselves while at the same time changing their 'relationship to themselves'. The hope is that those receiving care from the institutions governing them will convert with conviction to the mode of being expected of them, and will 'sincerely' transform their selves to become better individuals. It therefore appears that these politics work by making constraints 'reflexive'. Institutions act upon individuals' subjectivity in terms of encouraging them to conform to expectations, working upon them, changing them, compelling them to do things, and subjectivizing them - all with the aim of producing particular types of subjects.

\section{Conflicting rationalities}

However, direction does not always 'succeed' as a technique of government, as it does not always align governed people with the objectives and views of those who govern. If institutional support encourages introspection, verbalization, and selfevaluation, governed subjects may work on themselves in ways that differ from professional expectations. Therefore, direction is an invitation to self-reform that individuals may sometimes embody without aligning themselves with institutional goals.

At the Adoption Bureau, social worker Nadine meets that day with Ms Lebic. Nadine knows Ms Lebic well, as she has supported her through previous applications. Ms Lebic is a single woman ${ }^{10}$ who has already adopted two children with the support of the unit. A plump blonde lady of 35, wearing jeans, trainers, and a pink t-shirt, she comes to the unit wanting to extend her family further. She holds an administrative position at a center for children with Down's syndrome, and only wants to adopt children with this genetic condition. She is already mother to Josef (six years old) and Ondine (two years old) and is applying for approval for a third adoption.

Before the interview, Nadine explained to me that she had mixed feelings about Ms Lebic's plans. While Nadine recognized that this request presented an opportunity 'to find a family for children most applicants don't want', she wondered about the nature of such a perplexing desire. Ms Lebic comes into the social 
worker's office and, after the usual pleasantries, begins by explaining her current situation. She places a lot of emphasis on 'the love uniting' her family and 'everything that the children bring' her. However, Nadine has doubts about this idyllic perspective, questioning in particular the care required by the oldest child. In fact, Josef's Down's syndrome is extremely disabling: the child is still not toilet-trained at the age of six and has a substantial developmental delay, restricting his mobility and requiring a demanding level of institutional support. The social worker decides to express her concerns to the applicant:

In my opinion, there's already a really heavy burden of care to bear ... This third planned adoption ... in the same vein ... [...]

I don't know... we must see things differently.

How do you manage to deal with everything?

It's just a way of seeing things. I'm a very calm person. I'm not exceptional; I've maybe just made an exceptional choice. And I have friends who had this happen to them [raising a child with Down's syndrome] and that's just the way it is.

Yes... but for you, it's different; it's a choice.

It's a way of seeing life. For me, it's just a question of organization, that's all. And my children make me see life differently. It's not religious or anything... We take more time. It's a way of seeing life and I adapt to them.

So why three, then? Why not just stick to two?

Life is beautiful.

Ms Lebic replies gently to the questions asked by the social worker, but resists Nadine's practical arguments firmly. She outlines her timetable in great detail and explains how her life is organized to facilitate her children's education. ${ }^{11}$ Nadine then shifts the interview towards the applicant's personal life and tries to probe a lifestyle that she perceives as sacrificial.

And what about your own life, Ms Lebic?

Me? I'm fine [...] I think I know myself well.

And do you know when to stop?

I only do the things I want to do. I've talked with you a lot. All that, it's helped me to get to know myself. 
Nadine attempts to test the 'boundaries' that Ms Lebic should be capable of setting. However, after two successful applications, the applicant is used to this argument and counters this recurrent lever used in the approval interviews. Unlike many applicants who are disconcerted by the professionals' questions, Ms Lebic shows an ability to engage in reflexive thinking, acquired through her previous experiences, while also expressing the sense of recognition that is expected of her. She even adds that 'all that, it helped me to get to know myself'; according to her, it is even 'easier to raise a child with Down's syndrome than a child in good health'. She states that she is 'capable of giving children love, of playing with them, spending time with them, but that [she] wouldn't know how to push a child academically or to teach him that life is hard'.

Faced with an applicant who seems to assert a disconcerting degree of optimism, Nadine shifts her interrogation towards the technical register of good parenting practices. Her intention is to use an imaginary situation to test the applicant, and to assess how she would react to a practical projection (and how she verbalizes her reaction).

Ok, so you want a third child. But you only have two knees and two arms. What will you do about hugs?

Well... I can't really say, it'll happen spontaneously. But I have enough love for everyone, we'll take our time. They'll each have their turn.

Ok, but it will probably be difficult... [...] And later, when they're older, how will you deal with their sexuality? There's a risk of incest between the children...

Oh no, I'll tell them that they are brothers and sisters above all! Of course I imagine they'll have their own sexuality later, but not among themselves. And why not letting them having children? I can't exactly see myself forbidding it. Especially me [laughter].

I don't have any more arguments... I surrender. It seems a superhuman endeavor to me, but these aren't my choices. What more can I say?

After discussing Ms Lebic's case in a team meeting and consulting with the referring psychologist, Nadine recommended rejecting the application and the approval committee followed suit a few days later. As she explained to me in a private conversation, 'it was too much', there was 'something problematic' in the request and - without necessarily being able to put her finger on it - she felt 'obliged' to reject this application. As in Ms Lebic's case, ordinary professional ethics (Lambek, 2010) are sometimes ambiguous, despite the fact that they are located 'at the heart' of professionals' activity and commitment (Fassin et al., 2015), wherein workers are asked to judge and govern not only behaviors or abilities but also tempers and 'souls' (Rose, 1990). As a result, their decisions can be even harder to make, because they are less a question of punishing parents 
than of protecting hypothetical children, put in jeopardy by a parental desire that is always-already suspected of being selfish, immature, or incomplete (and sometimes even presented as pathological, as in the case above).

However, at the end, the pedagogy experienced and endured by the applicants tends to result in normalization, as they choose to cede and/or conform themselves. However, some applicants resist and force the administration to explicitly justify their exclusion; direction, as it depends on people's convictions, does not necessarily lead to conversion. It appears more as a 'soft' process that might sometimes be challenged, even if consequences demonstrate how powerful the apparatus remains.

Eloise is a 36-year-old woman of fragile appearance, with worn features. Her husband is an officer in the army, and they relocate regularly for his work. After living in the southeast of France for two years, the couple has just moved to a periurban town in the Paris suburbs. They recently bought a flat, where they live with their 18-month-old daughter and Eloise's first child, an 11-year-old boy from a previous relationship. Eloise works as a logistician but is on parental leave. She is four months pregnant when she comes to her first consultation at the unit for prenatal depression. She explains that she feels 'terribly lonely and isolated'. As her first daughter was born prematurely, she is worried about the end of this pregnancy: Will she be able to carry her baby to full term? Will she be able to protect the newborn, even though she couldn't bear her daughter - as she confessed, with guilt and shame - 'inside of her'? Eloise also admits that she is worried in particular about having to leave her children with her parents-in-law - both retired agricultural workers - while in the hospital. She says that given the geographical distance, she finds it difficult to deal with intra-family relationships and to keep 'the grandparents' (both her parents and her parents-in-law) happy, especially as her husband apparently leaves it 'all up to her'. During her appointment, Eloise cries. The psychologist finds her 'very depressed'. She encourages Eloise to 'let the tears come' and to continue telling her story, without holding back. The session ends with another appointment being made. In the doorway, as the patient is leaving, the psychologist adds: 'You should perhaps see the child psychiatrist so that he can give you something to make you feel better'.

The psychologist is concerned about the patient's state: 'I don't want to push her, she seems very fragile but I'm going to have to dig a little deeper next time. There's clearly some form of unresolved family issue in what she said about the grandparents'. During the next appointment, Eloise claims she feels much better, but nonetheless cries throughout a considerable part of the session. She agrees this time to meet the child psychiatrist who prescribes her some anti-depressants, but she refuses to take them, saying that 'for the moment, talking's enough'. The professionals agree among themselves, however, that although she does talk about her daily life, she does not 'sufficiently develop' the issues related to her childhood and her relationship with her parents, which would have allowed her to identify the subconscious reasons underpinning her present unhappiness. It is up to the young woman to take 'the chance she is being offered', she has to play an active role in the process. It is not enough to want peace of mind; it has to result from 
a personal effort, from working upon oneself, which is ultimately the patient's responsibility.

A month after she began receiving care, during what she has decided would be her last appointment, she does not cry at all. She announces that she has spoken to her husband about it all and says she feels much better: 'I'm not surprised that I was like this, I'm pregnant and I'm anxious. I'm on parental leave, far from my job, I'm isolated, I don't see any colleagues or any friends: I needed to talk'. But in the psychologist's opinion, this improvement is in fact a denial and just a further mark of the dysfunctional situation that justifies her involvement. The professional insists on telling the patient that '[her] door is always open if [she] needs it' and adds afterwards to the sociologist that, from a clinical viewpoint, this sort of "very rational and operational' discourse is the sign of a much deeper disorder.

Surely, as this situation shows, the institution sometimes has difficulty convincing subjects of the relevance of its involvement. However, even when care provision fails, its principle and its raison d'etre are safeguarded and justified: it is the subjects who were not capable of 'being aware of' or 'realizing the depth of their unhappiness', or of 'accepting to receive care'. According to the psychologist, Eloise's denial may cause serious trouble in her life. However, as the child's future is not in direct jeopardy, the institution does not insist on treatment, and withdraws. In the liberal tradition upon which psychological treatment is based, self-government is at its most successful when it results from a desire to be governed. No 'real' cure can occur without the desire to be cured.

Ms Lebic and Eloise were and are governed by the same apparatus. The women both act according to the institution's expectations: they are reflexive, they verbalize their difficulties, they ask themselves how to feel and behave adequately. However, to the extent that they are subject to direction as a technique of government - and, paradoxically, despite their expressed gratitude for what they have 'learned' about themselves and others - they have oriented themselves to a type of questioning - lines of inquiry - that institutions do not valorize. As such, these situations demonstrate how conflicting rationalities may occur within the field of institutional support. One might adhere to the prescribed process without being rewarded for doing so. Questioning oneself is not enough; questions have to be 'properly' formulated (i.e. in the very same terms that professionals and experts do $)^{12}$ in order to satisfy.

\section{Parentality as ethopolitics}

Some contemporary institutions call upon subjects to voluntarily transform themselves into 'better' selves, who conform to expectations, especially when it involves the necessity 'to love the ones who need to be loved', i.e. their children. However, by intervening in the 'private sphere' of attachments and family bonding, these institutions not only police emotions, they also encourage individuals to transform the relationships they have with themselves and others, by modifying behaviors, practices and affects in adherence with a core of new beliefs the individuals 
themselves consider to be of superior value. As such, institutional policies disseminate a specific ethics requiring self-transformation and auto-regulation, and analyzing this process can shed light not only on current power relations but also on the mechanisms at work in producing contemporary subjectivities (Mahmood, 2011; Zigon, 2010).

To conclude, we suggest that this institutional work involved in helping people transform themselves into newly desired and more desirable subjects corresponds to a form of 'ethopolitics'. Nikolas Rose defines it as the 'ways in which the ethos of human existence - the sentiments, moral nature or guiding beliefs of persons, groups, or institutions - have come to provide the 'medium' within which the self-government of the autonomous individual can be connected up with the imperatives of good government' (2001: 19). According to Rose, this form of government is highly reflexive: '[I]f discipline individualizes and normalizes, and biopower collectivizes and socializes, ethopolitics concerns itself with the selftechniques by which human beings should judge themselves and act upon themselves to make themselves better than they are' (2001: 19). As such, discourse and practices surrounding the idea of parentality have not only encouraged codifying and systematizing practical knowledge about how to act; they have also problematized the relationship which subjects have to themselves. Asking oneself, as a parent or a parent-to-be, the questions 'How should I act?' and 'What should I do?' has become systematically linked with the evaluation of one's own capacities ('How should I be?', 'Am I capable of ...?') as well as with the ethical meaning given to them: 'Is it good for me to be(come) a parent, given what I now know about myself?'

Doubtlessly, a full and accurate analysis of this form of government would require greater attention to the social affiliations of the people deploying these policies for self-reformation, and of those who subscribe to or resist them. In the two field studies outlined here, some subjects seemed more disposed to responding to these forms of government than others. In the two institutions examined, where there was an expectation for an introspective and reflexive subject, we found that there were more middle-class women among those who gave directions and those who subscribed to them. We can therefore hypothesize that self-adjustment remains a socially situated and gendered concern.

Nonetheless, although this analysis warrants further refinement, these fieldworks reveal systems of logic and techniques of government that can shed light on our understanding of current power relations and the liberal context in which they are taking shape. In fact, the study of techniques of care and control used in the field of parentality shows how politics of control and regulation that are deployed in the privacy of the family sphere act on an ethical level by inviting subjects to reform themselves for their own good and for the good of others. These forms of government are never thought of as constraints, restrictions, or policing, but rather as help, support, protection, or guidance; furthermore, they are based on the active participation of those being governed. These subjects, who are partly convinced of their need to be 'taken on' by the system, look to change 
themselves to the greatest extent possible. Whether they are considered suspicious (in the case of adoption) or suffering (in that of maternal mental health), they are called upon to demonstrate submission as testimony of their future abilities. And this submission can only be understood by realizing the full extent of their paradoxically voluntary subscription to the power to which they are subjected.

As such, subjects are persuaded by the authority to which they are subjected, and henceforth share the conviction that they reach a higher state of self-awareness - including through the repression they suffer, or the control they experience - and that this makes them morally superior. 'Achieving awareness' - whether through or for the apparatus aimed at creating their conformity - can make subjects give up on their initial desire of their own free will, as their previous (and objective) interests are subsumed within newly acquired ethical principles. And this study of parentality as ethopolitics demonstrates how, in some cases and situations, people do not only accept to be governed but also desire it and promote it - as the techniques of control which are deployed and set up 'help' them in becoming the ones they consider of superior value themselves: 'good' parents.

\section{Acknowledgements}

We would like to thank Jérôme Courduriès, Mélanie Gourarier, Sarah Mazouz and Michela Villani for their advice and comments on previous versions of this work, and Daniel Frazier and Lucy Garnier for their help during the translation process.

\section{Declaration of Conflicting Interests}

The author(s) declared no potential conflicts of interest with respect to the research, authorship, and/or publication of this article.

\section{Funding}

The author(s) disclosed receipt of the following financial support for the research, authorship, and/or publication of this article: This article is based on research supported by the Agence Nationale de la Recherche (France) under the grant ANR-14-CE29-0002-01 (Program ETHOPOL). This work also received support from Iris (Paris) and LISST-CAS (Toulouse).

\section{Notes}

1. In her book Mothering the Self, Stephanie Lawler (2000) studies the social efficacy of knowledge, according to which (good) mother-child relationships make (good) children. By analyzing the accounts of women, she examines how they forge their identity by making sense of, and negotiating with, pre-existing categories such as 'motherhood'. In doing so, she assesses the ways in which maternal selves are produced, and describes how they turn themselves into maternal subjects. Drawing on her constructivist theoretical framework, we suggest broadening Lawler's formula ('mothering the self') to put into question the ways by which individuals become parents through institutional activities ('parenting the self'). 
2. Usually, these women have no intention of ending their pregnancy. Given that they are referred by maternity care-workers whom they encounter after the pregnancy has been declared, these women are in their second trimester at the very earliest, which is after the legal limit for abortion in France.

3. The French term used here was 'cheminement', which has a secularized religious dimension that is important in understanding how value is placed on the cultivation of self.

4. More precisely, the notion of 'parentalité' was introduced in France by the psychiatrist Paul-Claude Racamier in 1961 as a translation for 'parenthood' - as originally defined and used by Dr Therese Benedek (Hounet, 2014).

5. In this article, we will translate 'parentalité' as 'parentality' for the purposes of distinguishing the notion from parenting and parenthood, as well as accentuating its ethical dimension when used in practice by social workers and psychologists (and the people they work with). We differ from other contemporary French analyses which still consider 'parentalité' as a translation for 'parenthood' only (Hounet, 2014). We think these perspectives tend to underestimate the cultivation of self that is encouraged by professionals. On the contrary, we promote an approach to 'parentality' more centered upon both institutions and individuals in order to study the subjectivization processes at stake.

6. Relying on full-term breastfeeding mothers' narratives, Charlotte Faircloth (2013) examines how intensive mothering is not only a way of child-rearing, but also a process by which selves are cultivated.

7. Patients are invited to explore their memories and their histories to identify the origin of their present difficulties. This process therefore brings to light a fair amount of 'abandonment issues', 'childhood issues', 'unresolved grief', etc., which locate the trauma (and its 'empire') (Fassin and Rechtman, 2009) at the heart of dysfunction - at the same time, pathologizing 'emotional abnormality' and giving hope for its possible cure.

8. Women's ambivalence towards motherhood, portrayed by feminist writer Adrienne Rich in Of a Woman Born (1976) as the conflict between institutionalized motherhood and women's drive for self-preservation, is here pathologized rather than understood as the result of competing internalized expectations about the feminine role.

9. Antoine and Nicolas were considered as 'children with special needs', as the two had to be adopted as brothers. This category also includes children suffering from curable or incurable diseases or disabilities, and children older than seven. In France, parents who take on children with special needs receive specific training and advice, as these children are considered particularly fragile and vulnerable.

10. In France, adoption is open to single people over 28 years old, whatever their sex. In practice, such adoptions are almost exclusively restricted to women who declare themselves single.

11. For a study about the subjective effects and practical consequences of mothering children with disabilities, see Landsman (2008).

12. Divergences may also be a mark of class differences and social relations. Our data do not allow us to elaborate further on this, but it seems that conflicting rationalities are also a product of social positions.

\section{References}

Apple R (2006) Perfect Motherhood: Science and Childrearing in America. New Brunswick, NJ: Rutgers University Press. 
Bartky SL (2003) Foucault, femininity and the modernization of partriarchal power. In: Weitz R (ed.) The Politics of Women's Bodies, Second Edition. New York: Oxford University Press, pp. 25-45.

Berman E (2014) Holding on: Adoption, kinship tensions, and pregnancy in the Marshall Islands. American Anthropologist 116(3): 578-590.

Boellstorff T (2007) A Coincidence of Desire: Anthropology. Queer Studies, Indonesia. Durham: Duke University Press.

Carsten J (2003) After Kinship. Cambridge: Cambridge University Press.

Davis-Floyd RE (2004) Birth as an American Rite of Passage, Second Edition. Berkeley: University of California Press.

De Certeau M (1984) The Practice of Everyday Life. Berkeley: University of California Press. Donzelot J (1979) The Policing of Families. New York: Pantheon Books.

Faircloth C (2013) Militant Lactivism? Attachment Parenting and Intensive Motherhood in the $U K$ and France. Oxford: Berghahn Books.

Faircloth C, Hoffman DM and Lyane LL (eds) (2013) Parenting in Global Perspective: Negotiating Ideologies of Kinship, Self and Politics. New York: Routledge.

Fassin D and Rechtman R (2009) The Empire of Trauma: An Inquiry into the Condition of Victimhood. Princeton: Princeton University Press.

Fassin D, et al. (2015) At the Heart of the State: The Moral World of Institutions. London: Pluto Press.

Foucault M (2014a) Wrong-Doing, Truth-Telling: The Function of Avowal in Justice. Chicago: University of Chicago Press.

Foucault M (2014b) On the Government of the Living: Lectures at the College de France, 1979-1980. New York: Palgrave Macmillan.

Fox B and Neiterman E (2015) Embodied motherhood: Women's feelings about their postpartum bodies. Gender \& Society 29(9): 670-693.

Fuchs RG (1984) Abandoned Children: Foundlings and Child Welfare in Nineteenth-Century France. Albany: State University of New York Press.

Furedi F (2002) Paranoid Parenting: Why Ignoring the Experts May Be Best For Your Child. Chicago: Chicago Review Press.

Godelier M (2012) The Metamorphoses of Kinship. New York: Verso.

Goody EN (1982) Parenthood and Social Reproduction: Fostering and Occupational Roles in West Africa. Cambridge: Cambridge University Press.

Hays S (1996) The Cultural Contradictions of Motherhood. New Haven: Yale University Press.

Homans M (2006) Adoption narratives, trauma, and origins. Narrative 14(1): 4-26.

Hounet YB (2014) La parentalité des uns. . et celle des autres. L'Homme 209: 12-141.

Howell S (2006) Kinning of Foreigners: Transnational Adoption in a Global Perspective. New York: Berghahn Books.

Hulbert A (2004) Raising America: Experts, Parents, and a Century of Advice About Children. New York: Vintage.

Laidlaw J (2013) The Subject of Virtue: An Anthropology of Ethics and Freedom. Cambridge: Cambridge University Press.

Lambek M (2010) Ordinary Ethics: Anthropology, Language, and Action. New York: Fordham University Press.

Landsman G (2008) Reconstructing Motherhood and Disability in the Age of 'Perfect' Babies. New York: Routledge. 
Lawler S (2000) Mothering the Self: Mothers, Daughters, Subjects. London: Routledge.

Lee E (2004) Abortion, Motherhood and Mental Health: Medicalizing Reproduction in the United States and in Great Britain. New Brunswick, NJ: Transaction Publishers.

Lee E, et al. (2014) Parenting Culture Studies. New York: Palgrave Macmillan.

Lupton D (2000) 'A love/hate relationship': The ideals and experiences of first-time mothers. Journal of Sociology 36(1): 50-63.

Lupton D and Barclay L (1997) Constructing Fatherhood: Discourses and Experiences. London: Sage.

Lynch KA (1988) Family, Class, and Ideology in Early Industrial France: Social Policy and the Working-Class Family, 1825-1848. Madison: University of Wisconsin Press.

Mahmood S (2005) Politics of Piety: The Islamic Revival and the Feminist Subject. Princeton: Princeton University Press.

Martin C (2003) La parentalité en questions, perspectives sociologiques: rapport pour le Haut conseil de la population et de la famille. Paris: Haut conseil de la population et de la famille.

May V (2008) On being a 'good' mother: The moral presentation of self in written life stories. Sociology 42(3): 470-486.

Rich A (1976) Of a Woman Born: Motherhood as Experience and Institution. New York: W.W. Norton.

Rose N (1990) Governing the Soul: The Shaping of the Private Self. New York: Routledge.

Rose N (2001) The politics of life itself. Theory, Culture \& Society 18(6): 1-30.

Strathern M (1992) Reproducing the Future: Anthropology, Kinship, and the New Reproductive Technologies. New York: Routledge.

Taylor V (1996) Rock-a-by Baby, Feminism, Self-help and Postpartum Depression. New York: Routledge.

Weber F (2005) Le sang, le nom, le quotidien: une sociologie de la parenté pratique. La Courneuve: Aux lieux d'être.

Zigon J (2010) 'HIV Is God's Blessing': Rehabilitating Morality in Neoliberal Russia. Berkeley: University of California Press.

\section{Author Biographies}

Sébastien Roux is a CNRS researcher at the Laboratoire Interdisciplinaire Solidarités, Sociétés, Territoires (LISST) in Toulouse (France). Anthropologist and Sociologist, he works on policies pertaining to children, adoption, gender and sexuality, and the anthropology of morals and ethics. He conducted research in Thailand (on sex tourism), France (on juvenile delinquency), and Ethiopia (on transnational adoption). As PI of the grant ANR ETHOPOL, he leads a team of social scientists working on the government of intimacy and emotions, in Toulouse and Paris. Within this program, his fieldwork is concentrated on the international circulation of children for adoption purposes, and the intimate politics of borders.

Anne-Sophie Vozari is a doctoral student in the Social Sciences at the Institute of Interdisciplinary Research on Social Issues (Institut de Recherche Interdisciplinaire sur les enjeux Sociaux, IRIS, UMR 8156), School for Advanced Studies in the Social Sciences (Ecole des Hautes Etudes en Sciences sociales, EHESS) in Paris. 
Her research focuses on parenting and birth policies, care professions and gender. Her doctoral thesis examines the institutional management of motherhood around birth in France. She has conducted several ethnographic investigations in different maternity units as well as in maternal and child health centers. Within the ANR ETHOPOL program, she studies the subjective consequences of care provided for maternal depression. The empirical examination of this psychic and psychiatric treatment aims at understanding how women who are unable to feel or think "maternally" are made into "mothers" with the support of health professionals. 